\title{
Cks1: Structure, Emerging Roles and Implications in Multiple Cancers
}

\author{
Vinayak Khattar', Jaideep V. Thottassery ${ }^{1,2}$ \\ ${ }^{1}$ Southern Research Institute, Birmingham, USA; ${ }^{2}$ University of Alabama Comprehensive Cancer Center, Birmingham, USA. \\ Email: thottassery@sri.org
}

Received August $12^{\text {th }}, 2013$; revised September $10^{\text {th }}, 2013$; accepted September $17^{\text {th }}, 2013$

Copyright (C) 2013 Vinayak Khattar, Jaideep V. Thottassery. This is an open access article distributed under the Creative Commons Attribution License, which permits unrestricted use, distribution, and reproduction in any medium, provided the original work is properly cited.

\begin{abstract}
Deregulation of the cell cycle results in loss of normal control mechanisms that prevent aberrant cell proliferation and cancer progression. Regulation of the cell cycle is a highly complex process with many layers of control. One of these mechanisms involves timely degradation of CDK inhibitors (CKIs) like p2 $7^{\mathrm{Kip} 1}$ by the ubiquitin proteasomal system (UPS). Cks1 is a $9 \mathrm{kDa}$ protein which is frequently overexpressed in different tumor subtypes, and has pleiotropic roles in cell cycle progression, many of which remain to be fully characterized. One well characterized molecular role of $\mathrm{Cks} 1$ is that of an essential adaptor that regulates $\mathrm{p} 27^{\mathrm{Kip} 1}$ abundance by facilitating its interaction with the SCF-Skp2 E3 ligase which appends ubiquitin to $\mathrm{p} 27^{\mathrm{Kip} 1}$ and targets it for degradation through the UPS. In addition, emerging research has uncovered $\mathrm{p} 27^{\mathrm{Kip} 1}$-independent roles of $\mathrm{Cks} 1$ which have provided crucial insights into how it may be involved in cancer progression. We review here the structural features of Cks1 and their functional implications, and also some recently identified Cks1 roles and their involvement in breast and other cancers.
\end{abstract}

Keywords: Cks1; Cks2; Skp2; Cdk1; p27; Kip1; p130; Rb2; CKI; Ubiquitination; Proteasome; ERK1/2

\section{Introduction}

Regulation of the cell cycle is crucial for cellular proliferation and survival $[1,2]$. The engines that drive the cell cycle include cyclin dependent kinases (CDKs) and their activating cyclin subunits which oscillate during the cell cycle and thus modulate the activity of CDKs at specific points in various cell cycle phases [3]. Another level of control requires the action of cyclin dependent kinase inhibitors (CKIs) on CDKs [4]. These CKIs, along with other cell cycle substrates are regulated by precise and coordinated proteasomal degradation [5,6]. This in turn can regulate the activities and abundance of other substrates $[5,6]$.

The ubiquitin proteasomal system (UPS) employs a series of activating (E1), conjugating (E2) and ligase (E3) enzymes and appends ubiquitin chains to substrates, and directs them to timely degradation by the proteasomal machinery [7]. For instance a crucial step in regulating mammalian G1-S transition is one which involves the degradation of $\mathrm{p} 27^{\mathrm{Kip} 1}$ by the UPS, which is required for full activation of cyclin E-CDK2 complexes [8,9]. Following its phosphorylation on Thr- 187 by cyclin E-Cdk2, $\mathrm{p} 27^{\mathrm{Kip} 1}$ is ubiquitinated by the SCF-Skp2 E3 ligase [10].
Ganoth et al. demonstrated that fully reconstituted SCFSkp2 only ubiquitinates $\mathrm{p} 27^{\mathrm{Kip} 1}$ when it is supplemented with Cks1 [11,12]. Investigations revealed that Cks1 interacts with the substrate recognition component in this complex, Skp2, and facilitates its $\mathrm{p} 27^{\mathrm{Kip} 1}$ ubiquitination activity $[12,13]$. Until recently this was the only well characterized molecular role for $\mathrm{Cks} 1$ in mammalian systems. However, emerging research reveals many more diverse and $\mathrm{p} 27^{\mathrm{Kip} 1}$ independent roles of Cks1 that encompass growth signaling pathways [14-25], apoptosis [25] and even DNA damage responses [26,27].

Cks1 was discovered in 1986 in a screen that identified genes that allow temperature sensitive cdc 2 mutants in yeast to grow at the restrictive temperature [28-30]. The screen identified a molecule called Suc1 (Suppressor of cdc2) which when present on multicopy plasmids in Schizosaccharomyces pombe could rescue cells mutated in their cdc2 [28]. The study hinted that the action ofSuc1 was specific to cdc2 suggesting direct interaction between the two [28,29]. Indeed it is now recognized that Cks1 (Suc1 in S. pombe) does interact with CDKs at a site that is distinct from their ATP binding or cyclin binding sites [31-33]. Further characterization revealed 
that overexpression or mutations in Suc1 caused defects in the cell cycle and in viability showing that this gene was crucial for cell cycle progression [34].

\section{Structure and Functional Implications}

\subsection{Sequence, Secondary and Higher Order Structure}

The sequence of the Cks family of proteins is highly conserved across species $[31,35,36]$. Exploiting this similarity Richardson et al. designed degenerate primers allowing them to clone the human orthologs CksHs1 and CksHs2 from a HeLa cDNA library [37]. Comparison of CksHs1 and CksHs2 reveals $81 \%$ identity between the two molecules [37]. The evolutionary logic behind this conservation can be appreciated in the context of the crucial role of Cks1 in cell cycle and its interactions with CDKs [38]. For instance both human Cks proteins have identities higher than 50\% when compared with both the fission and budding yeast $\mathrm{Cks}$ sequences and are capable of rescuing a null mutation in the S. cerevisiae Cks1 gene [33,37].

Although there is a high level of conservation among Cks1 sequences across species, the length of Cks1 in $S$. Cerevisiae and $S$. pombe is 150 and 113 residues respectively, while the human orthologs, CksHs1 and CksHs2, are both 79 amino acids long $[31,35,36]$. The major differences that account for this difference in length are two extensions at the $\mathrm{N}$ and $\mathrm{C}$-terminals and a 9 amino acid insertion sequences in yeast $\mathrm{Cks}$ sequences not found in CksHs1 or CksHs2 [32]. The C-terminal extension in yeast sequences includes a 16 residue long polyglutamine tail and it has been observed that these Cks1 molecules can form fibrillar aggregates characterized by presence of specific hydrogen bonding between polyglutamine sequences $[35,36,39]$. The characteristics of these aggregates were found to be very similar to those observed in amyloid fibrils or aggregates observed in other polyglutamine deposition diseases on firm that you have the correct template for your paper size.

CksHs1 and CksHs2 have key structural differences at higher levels of structural organization despite their remarkable sequence identity. Arvai et al. determined the structure of Cks1Hs1 at a resolution of 2.9 A, and observed that the domain architecture and subunit conformation for CksHs1 and Cks1Hs2 are dramatically different [31]. Although theoretically both $\mathrm{CksHs} 1$ and CksHs2 can exist in monomeric and dimeric forms in vitro, it appears that Cks1Hs1 is more stable in monomeric form whereas CksHs2 was observed in primarily dimeric and even hexameric forms [31]. In vivo it is predicted that binding of CDKs and metal ions influences that stability and predominance of a particular form over the other $[31,40]$.

Nevertheless CksHs1 does crystallize as a dimer with anionic cofactors like vanadate, tungstate or phosphate
$[31,40]$. The CksHs1 dimer utilizes a crucial hydrogen bond between residues Tyr 8 present in the $\beta 1$ strand of each molecule [31]. The Cks1Hs1 monomer is a single polypeptide chain folded in a single domain comprising four anti-parallel $\beta$ sheets sandwiching two $\alpha$-helices [31]. Starting from the N-terminus the sequence of secondary structural elements includes two anti-parallel $\beta$ sheets $\beta 1$ and $\beta 2$ followed by two short $\alpha$ helices and finally two anti-parallel $\beta$ sheets $\beta 3$ and $\beta 4$ [31]. Following crystallization these monomers can assemble into dimeric form with eight $\beta$ sheets forming a twisted structure due to a tilt of 50 degrees between the two adjacent $\beta$ strands [31]. Despite the fact that both CksHs1 and CksHs2 molecules can form dimers, the folding of a small sequence conserved region between Glu 61 and His 65 results in dramatically different conformations for the $\beta 4$ strand resulting in he characteristic $\beta$ strand exchange form observed in CksHs2 [31]. Thus, depending on the conformation of this highly conserved region forming a $\beta$-hinge between $\beta 3$ and $\beta 4$ strands, Cks proteins can exist in two forms [31]. When this hinge region is in an extended conformation, it facilitates the $\beta 4$ strand from one monomer to fold out and interact with secondary structural elements of the other monomer [31]. Similarly the corresponding $\beta 4$ strand from the second monomeric domain extends out and "squeezes" itself between secondary structural elements on the other monomer of the Cks molecule thus resulting in characteristic structure termed $\beta$ strand exchange dimer [31]. On the other hand in a closed conformation this hinge region is more ordered and will exist as a $\beta$ bend preventing any such strand exchange between monomers [31]. In CksHs1 the $\beta$ hinge region is in this closed conformation and hence does not allow any $\beta$ strand exchange between the monomers [31]. On the other hand this conserved region is conformationally different in CksHs2 allowing it to assemble as a $\beta$ strand exchanged dimer [31].

These subtle differences in the $\beta$ hinge region that leads to dramatically different subunit conformation suggests a theory where a specific stimulus or cell cycle event may trigger a change from one form to another as a part of a regulatory mechanism [31]. This in turn could lead to changes in critical interactions between Cks and its partner proteins leading to other downstream physiological consequences [31]. Although, whether in fact such changes in domain architecture of CksHs1 do play a part in cell physiology remains speculation for the time being, Arvai et al. have pointed out that critical residues such as Tyr 12, Tyr 19 and Tyr 57 are exposed in the single domain fold whereas these regions are masked in dimeric or hexameric forms [31].

\subsection{Functional Implications of Structural Features in Cks1}

Functionally speaking Cks1 structure is characterized by 
the presence of three regions including a cdc2/CDK binding region, a Skp2 binding region and an anion/ phosphate binding pocket $[31,32,41-43]$ (see Table 1 for the key residues mediating the interactions in these functional regions). Another striking feature of Cks1 structure is that the CksHs1 molecule shows a strong homology to the N-lobe domain of CDK2 [31,32,41-43]. That Cks1 binds to cdc28 and cdc2 was already established during early coimmunoprecipitation studies with yeast homologs of Cks1 [44]. Similarly it was later demonstrated that Xe-p9 could also interact with $\mathrm{Cdc} 2 /$ cyclinB complexes [45]. The crystal structure of human CDK2 in complex with CksHS1 revealed that Cks1 utilizes all four beta sheets for this interaction and binds specifically to the C-terminal lobe of CDK [32]. Also it was revealed that the CDK domain does not interact with the cyclin binding sites or regulatory phosphate binding sites [32]. Cks1 can bind to CDK only in its monomer conformation and uses specific hydrophobic residues (see Table 1) as well as the conserved $\beta$-hinge region [32]. On the other hand the opening of this $\beta$ hinge, which is the characteristic feature of the beta strand exchanged dimer does not allow Cks to bind to CDK2 [32].

The ternary complex of Skp1-Skp2-Cks1 in association with a phosphorylated $\mathrm{p} 27^{\text {Kip }}$ peptide elucidated by Pavletich et al. has provided significant insights into how Cks1 influences recognition of $\mathrm{p} 27^{\mathrm{Kip} 1}$ by the SCF complex [42]. It is a sickle shaped binary structure where Skp1 and the F-box domain of Skp2 form the handle and the Skp2 leucine rich repeat (LRR) domain forms the curved blade [42]. The C-terminal tail of Skp2 at the end of tenth LRR curves inwards and interacts with first LRR. The Cks1 molecule docks into this concave groove form-

Table 1. Cks1 structural features and their functional implications.

\begin{tabular}{ccc}
\hline Property & Residue & Region and Contacts \\
\hline & & $\beta 1$ \\
Anion & K11 & $\beta 2$ \\
Binding & R20 & Between $\alpha 2$ and $\beta 3$ \\
Pocket (Binds & S51 & $\beta 3$ \\
pThr187 of & W54 & $\beta 4$ (all involved in \\
p27 ${ }^{\text {Kip1 }}$ ) & R71 & charge-stabilized \\
& & H-bonding) \\
& Y12 & $\beta 1$ (hydrophobic) \\
Cdk binding & Y19, H21, M23 & $\beta 2$ (hydrophobic) \\
region & Y57, M58 & Between $\beta 2$ and $\beta 3$ \\
& E60, P62, I66, L68, R70 & $\beta 4$ (hydrophobic) \\
& E63 & $\beta 4$ (H-bonding) \\
Skp2 binding & E40, S41, E42, N45 & $\alpha 2$ (H-bonding) \\
region & L31, P33 & $\alpha 1$ (van der Waals) \\
& H36, M38 & $\alpha 2$ (van der Waals) \\
Dimer & I6, Y7, D10 & $\beta 1$ (H-bonding) \\
interaction & H21 & $\beta 1$ \\
sites & M23, Q49 & between $\alpha 2$ and $\beta 3$ \\
\hline & &
\end{tabular}

ed by the LRR and C-terminal tail of Skp2. Three key residues (see Table 1) of Cks1 are required for H-bonding interactions with Skp2 and map into the 2 helix of Cks1 $[41,42]$. Phosphorylated p2 $7^{\text {Kip1 }}$ is recognized by phosphate binding pocket of Cks1 and p2 $7^{\text {Kipl }}$ forms regions of contacts with both Cks1 and Skp2 by inserting a crucial Glu185 residue in the interface formed between Cks1 and Skp2 [41,42]. Hydrogen bonding between highly conserved Skp2 residues (Trp265, Arg294, Asp319, and Arg344 side chains) and those of Cks1 (Ser41, Glu40, and Asn45 side chains and Ser41 carbonyl group) is a crucial prerequisite for Cks1-Skp2 interaction and hence altering these Cks1 residues is known to compromise the $\mathrm{p} 27^{\mathrm{Kip} 1}$ ubiquitination activity of the SCF complex [41,42]. The residues Ser41 and Asn 45, are replaced by Glu and Arg residues in CksHs2 precluding its interaction with Skp2 [41,42]. Yeast Skp2 is not known to interact with Cks1, although Cks1 in yeast does play a role in the multi-site phosphorylation of Sic1, the $\mathrm{CDK}$ inhibitor that is homologous to mammalian p2 $7^{\text {Kip1 }}$ [46].

The ubiquitination of $\mathrm{p} 27^{\mathrm{Kip} 1}$ is preceded by its phosphorylation at residue $\mathrm{Thr}^{187}$ which is then recognized by the phosphate binding pocket present in Cks1 $[31,41,42$, $47,48]$. Two anion binding pockets are present near the dimer interface within a crevice formed by the dimer association [31]. In fact negatively charged moieties like vanadate or tungstate were used to facilitate crystallization of CksHs1 by Arvai et al. [40]. Crucial van der Walls contacts and hydrogen bonding contacts from residues Lys11, Arg20 and Arg71 and to the main chain nitrogen atom of Ser51 stabilize the interaction with these moieties [42].

\section{Diverse Cellular Functions of Cks1}

Cks1 roles can be broadly classified into four categories: 1) roles in modulating cell cycle, 2) roles in transcription, 3) roles in growth signaling pathways, and 4) other emerging roles. Excellent reviews describing some of these functions of Cks1 are available [49-53].

\subsection{Cks1 Roles in Modulating the Cell Cycle}

The evidence for Cks1 modulating the cell cycle was provided by Tang and Reed where it was reported that loss of Cks1 in S. cerevisiae causes defects in both G1-S and G2-M transition [54]. However the mechanism by which Cks1 regulates G1-S transitions in mammalian systems was elucidated in two independent reports by Ganoth et al. and Spruck et al. which showed that Cks1 is indispensable for proteasomal degradation of $\mathrm{p} 27^{\mathrm{Kip} 1}$ $[12,13]$. Ganoth et al. showed that a fully reconstituted SCF-Skp2 complex cannot ubiquitinate p27 in-vitro unless it was supplemented by a crucial factor (Factor I) 
derived from the unbound fraction of the HeLa cell extracts fractionated on DEAE-cellulose columns [12]. Further purification and characterization of this unknown factor revealed that this factor was Cks1 [12]. Furthermore this report established that Cks1's role in p27 $7^{\text {Kip1 }}$ degradation was specific to the SCF-Skp2 ligase since it had no impact on the activity of other ubiquitin ligases like SCF $\beta$-TrCP [12]. Spruck et al. utilized MEFs derived from $\mathrm{Cks}^{-1-}$ mice [13]. $\mathrm{Cks1}^{-/-}$mice exhibit a smaller body size, which is possibly due to proliferative abnormalities (due to accumulation of $\mathrm{p} 27^{\mathrm{Kip} 1}$ in somatic cells during embryonic development) [13]. Interestingly the roles of $\mathrm{Cks} 1$ in $\mathrm{p} 27^{\mathrm{Kip} 1}$ degradation have been suggested to be independent of its interactions with CDKs. A Cks1 mutant defective in CDK binding (E63Q) has been shown to be capable of $\mathrm{p} 27^{\mathrm{Kip} 1}$ ubiquitination [13]. On the other hand other mutations in the CDK2 binding site of Cks1 do reduce the ability of cyclin A-CDK2 to promote $\mathrm{p} 27^{\mathrm{Kip} 1}$ ubiquitination [41]. Although phosphorylation of $\mathrm{p} 27^{\mathrm{Kip} 1}$ on residues Thr-187 by cyclin E/A-CDK2 complex is a crucial prerequisite for its recognition and proteasomal targeting by the SCF-Skp2 ubiquitin ligase, whether the interactions of Cks1 with CDK2 itself have any impact on its $\mathrm{p} 27^{\mathrm{Kip} 1}$ ubiquitination activity remains controversial $[13,41,42]$.

Three models have been suggested to describe the role of Cks1 in p27 $7^{\mathrm{Kip} 1}$ ubiquitination [50]. The first model suggests that binding of Cks1 to the C-terminal of Skp2 results in a necessary conformational change that allows the Skp2 to interact efficiently with its phosphorylated substrate, $\mathrm{p} 27^{\mathrm{Kip} 1}$. This model depicts a binding site of Cks1 wherein Cks1 docks in a concave groove formed by the LRR region and the C-terminal tail of Skp2 [42,50]. It is suggested that interaction of Cks1 with the C-terminal tail region of the Skp2 molecule "nudges" the occluding LRR region and allows efficient interaction between LRR and the phosphorylated substrate [42,50,55]. The second model suggests that Cks1 may physically act as an adaptor or bridge between phosphorylated substrate p2 $7^{\mathrm{Kip} 1}$ and F-box protein Skp2 [42]. It is possible that the phosphate binding site of Cks1 recognizes phosphorylated $\mathrm{p} 27^{\mathrm{Kip} 1}$ which is then brought in close proximity to Skp2 for ubiquitination [42]. Although it has been shown that Cks1 interaction with CDK2 is not necessary for $\mathrm{p} 27^{\mathrm{Kip} 1}$ degradation, it has been suggested in a third model that Cks1-CDK2 binding pulls out the p $27^{\text {Kip1 }}$-cyclin A-Cdk2 complex and favors its interaction with SCF-Skp2 complex [42]. Although further genetic and biochemical studies are required to distinguish between these possibilities, the role of Cks1 in p2 $7^{\text {Kip1 }}$ degradation is indisputable.

Cks1 also regulates the proteasomal degradation of $\mathrm{p} 130 / \mathrm{Rb} 2$ which is both a pocket protein and an inhibitor of CDK2 [56,57]. The expression of p130 is largely re- stricted to G0 phase of the cell cycle [56,57]. Like $\mathrm{p} 27^{\mathrm{Kip} 1}$ the turnover of $\mathrm{p} 130$ is regulated proteasomally [58]. As proliferating cells enter from G0 phase to G1, p130 gets phosphorylated by CDK $4 / 6$ complexes and is proteasomally degraded by a process which employs the SCF-Skp2 E3 ubiquitin ligase complex [58]. In fact loss of either Skp2 or Cks1 impairs proteasomal stability of p130 as evidenced by its accumulation in asynchronous or thymidine arrested $\mathrm{Skp}^{-/-}$and $\mathrm{Cks}^{-/-}$fibroblasts [58]. Thus Cks1 is responsible not only for regulating the p $27^{\text {Kip1 }}$ degradation but also plays a pivotal role in determining p130 stability in proliferating cells [58].

Cks1 has also been implicated in the degradation of mitotic substrates by regulating the APC/C ubiquitin ligase and spindle assembly checkpoint (SAC), which is crucial for orchestrating mitotic timing [59-62]. The SAC fine-tunes the timing of proteasomal degradation through APC/C ubiquitin ligase by inactivating its coactivator Cdc20 $[63,64]$. This in turn prevents premature degradation of APC/C mitotic substrates like securin and cyclin B1 ensuring accurate sister chromatid separation before mitotic exit $[63,64]$. However other APC/C substrates like cyclin A are degraded even though the $\mathrm{SAC}$ is still active [65]. Studies by Di Fiore et al. and Wolthius et al. have explained this paradox by showing that the N-terminus of cyclin A competes with SAC proteins to bind to Cdc20 [66,67]. Following this Cks1 recruits the cyclin A-cdc20 complex to a phosphorylated APC/C ubiquitin ligase, triggering cyclin A ubiquitination and subsequent proteasomal degradation. [66,67]. Furthermore it was demonstrated that the anion binding site of Cks1 is crucial for the SAC independent degradation of cyclin A $[66,67]$.

Loss of Cks1 also results in impaired mitotic passage in yeast and in Xenopus egg extracts [45,54]. In Xenopus egg extracts, Cks1 is crucial for dephosphorylation of Y15 residue of CDK1 [45]. Cks1 promotes MPF dependent phosphorylation of cdc $25 \mathrm{c}$ phosphatases, wee 1 and myt1 kinases, all molecules that participate in CDK1 activation by removing inhibitory phosphorylation from Cdk1 [45]. Xe-p9 (Xenopus homologue of Cks1) is also known to promote cyclin B1 degradation [68,69]. More specifically Xe-p9 regulates mitotic exit by stimulating phosphorylation of cdc27, another important component of the APC/C complex that targets cyclin B1 and several other mitotic molecules for proteasomal degradation, thus orchestrating mitotic exit in these cells $[68,69]$. Studies in our laboratory have shown that loss of Cks1 in MCF-7 breast cancer cells leads to blockade in mitotic entry with corresponding loss of CDK1 [70]. Furthermore the mitotic block can be rescued by reintroduction of exogenous CDK1 [70]. A report by Martinsson-Ahlzen et al. has also demonstrated that loss of Cks1 in MEFs and HeLa cells results in cell cycle arrest in G2 
phases which can be reversed reintroduction of cyclin B1 [71]. Interestingly Cks1 loss does not alter cell cycle profiles in human mammary epithelial cells (HMECs) or normal human lung fibroblasts [70,72].

Although G1-S defects following Cks1 loss in mammalian cells can be accounted for by $\mathrm{p} 27^{\mathrm{Kip} 1}$ accumulation, recent reports have indicated that some defects can also be explained in part by $227^{\text {Kipl }}$ independent mechanisms [73]. In studies reported by Keller et al. it was found that CDK1 kinase activity of the $\mathrm{Cks}^{-/-} \mathrm{MEF}$ cells was not altered whereas there is considerable loss in CDK2 kinase activity [73]. Furthermore concomitant loss of $\mathrm{p} 27^{\mathrm{Kipl}}$ in $\mathrm{Cks}^{-/-} \mathrm{MEF}$ did not rescue this loss in Cdk2 kinase activity indicating that part of G1-S defects observed are $\mathrm{p} 27^{\mathrm{Kip} 1}$ independent and a direct conesquence of Cks1 interaction with CDK2 activity [73]. In fact a report by Liberal et al. has shown that Cks1 can override DNA damage response by increasing CDK2 kinase activity and overriding the inhibitory effects of Y15 phosphorylation on CDK2 [27].

\subsection{Cks1 Roles in Transcription}

Recently Cks1 has also been implicated in transcriptional regulation [71,74-77]. In fact some of these transcriptional roles also indicate other ways by which Cks1 might be involved in regulating cell cycle transitions [71, 76]. For instance, Cdc20 has been shown to be a transcriptional target of Cks1 [76]. Cdc20 is a regulator which associates with and modulates the activity of the APC ubiquitin ligase during distinct phases of cell cycle [78]. It was shown that Cks1 is essential for dissociation of $\mathrm{Cdc} 28$ from $\mathrm{Cdc} 20$ promoter and recruitment of specific proteasomal subunits like Rpt1, Prel on this promoter [76]. It has been suggested that this periodic association and dissociation events on the $\mathrm{Cdc} 20$ promoter facilitates remodeling of transcriptional complexes docked on the Cdc20 promoter [76]. It has also been recently reported that that Cks1 plays a role in GAL1 transcription, whereby Cks1, CDK1 and the 19S subunit of the proteasome are recruited to the GAL1 promoter, specifically attaching to the histone $\mathrm{H} 4$ amino-terminal tail of the chromatin [74]. This activity has been reported to alter nucleosome density and evict nucleosomes from the chromatin region thereby inducing GAL1 transcription [74]. Cks1 has also been shown to transcriptionally regulate the expression of $c d c 2$, cyclin $B$ and $\operatorname{cyclin} A$ in mammalian cells [71].

The regulation of Cks1 gene expression itself is now known to be regulated through transcriptional mechanisms [79-87]. Cks1 mRNA levels start rising in late G1 reaching a peak before the onset of S-phase [88]. Another peak is observed at $\mathrm{G} 2 / \mathrm{M}$ phase of the cell cycle [37]. Various reports have provided insights into possible transcriptional regulators for Cks1 [79-86]. Mutating a potential CDE/CHR (cell cycle dependent element and cell cycle genes homology region) tandem repeat within Cks1 promoter compromises transcriptional activation of Cks1 indicating that this element acts as a possible transcriptional regulator [87]. Although Cks1 does not have p53 binding site, forced induction of p53 represses mRNA and protein expression of Cks1 possibly due to p53 dictated repression of Cks1 promoter [87]. On the other hand NF-Y, FoxM1, and Myc are known to act as transcriptional activators for Cks1 $[80,81,83,85,87]$. In fact Myc induced Cks1 activation has been proposed to be a switch that triggers p $27^{\text {Kip1 }}$ loss and subsequent cell proliferation and tumorigenesis by Keller et al. [81].

In primary T-lymphocytes CD28 along with T-cell receptor (TCR) provides a co-stimulatory signal that is required for $\mathrm{T}$ cell activation and entry into S-phase [89, 90]. CD28 co-stimulatory signals downregulate $\mathrm{p} 27^{\mathrm{Kip} 1}$ by inducing transcription of Skp2 and Cks1, thus enhancing its proteasomal degradation [79]. TGF-treatment of mink lung epithelial cells and Hep3B cells also decreases Cks1 mRNA transcripts, and this loss of Cks1 has been known to compromise $\mathrm{p} 27^{\mathrm{Kip} 1}$ ubiquitination, and also triggers Skp2 autoubiquitination and degradation [86]. Furthermore, B-Raf and cyclin D1 also downregulate Cks1 expression at the mRNA and protein levels [15]. Despite many reports of Cks1 roles in transcription and the transcriptional regulation of Cks1 by other proteins, many gaps remain in our knowledge regarding the mechanisms of both these phenomena and require further investigation.

\subsection{Cks1 Roles in Growth Signaling Pathways}

The roles of Cks1 in growth factor signaling pathways have started to emerge with few studies suggesting the involvement of Cks1 in MAPK, JAK-STAT and NF-B pathways [13-24]. Despite its crucial role in cell cycle and cancer progression, mechanistic studies regarding Cks1 role in growth signaling mechanisms are lacking. Cks1 siRNA knockdown decreases ERK1/2 phosphorylation and triggers apoptosis in breast cancer cells MDAMB-231 whereas its overexpression inhibits apoptosis and increases ERK1/2 phosphorylation hinting at a Cks1 modulated signaling event in this important pathway [25]. Another study showed that Cks1 shRNA mediated knockdown leads to decrease in ERK1/2, MEK and STAT phosphorylation in multiple myeloma cell lines KMS28PE, OCI-MY5 and XG-1 whereas forced overexpression of Cks1 activates ERK1/2 and STAT phosphorylation in the later two cell lines [21]. Surprisingly Skp2 knockdown or $\mathrm{p} 27^{\mathrm{Kip} 1}$ overexpression caused suppression of ERK/MEK and JAK/STAT signaling indicating that Cks1 may be involved at a crucial node of 
regulation of signaling events independently of Skp2 and p2 $7^{\text {Kip1 }}[21]$.

Although the role of Cks1 upstream of these kinases at the level of Ras GTPases and Raf kinases has not been investigated, squamous cell carcinomas and lung adenomas derived from RasH2 mice have been shown to exhibit fluctuations in levels of Cks1 when treated with genotoxic agents like 7,12-dimethylbenz[a]anthracene (DMBA), urethane and N-ethyl-N-nitrosourea (ENU) [91]. It has also been shown that adaptor protein FGF receptor 2 (FRS2) associates with Cks1 and FGF dependent phosphorylation of FRS2 releases Cks1 and causes concomitant $\mathrm{p} 27^{\mathrm{Kip} 1}$ degradation in $3 \mathrm{~T} 3$ cells [24]. Recently the role of Cks1 in NF-B induced hepatocellular cancer has also been reported whereby Cks1 transcriptionally regulates IB and hence drives NF-B mediated IL-8 driven hepatocellular carcinoma [19]. Given that Cks1 is overexpressed in several different tumor types, its role as a signaling modulator remains a fruitful and unexplored avenue of research.

\subsection{Other Roles of Cks1}

Although the majority of research on Cks1 has been conducted using yeast and mammalian systems, there are a number of studies that have utilized other systems including Xenopus laevis [45], Caenorhabditis elegans [92], Drosophila melanogaster [93], Branchiostoma belcheri tsingtauense [94], Leishmania Mexicana [95] and Patella vulgate [96]. Cks1At, an A. thaliana homolog of Cks1 was shown by Montagu et al. to bind to arabidopsis CDKs Cdc2aAt and Cdc2bAt [97,98]. Further characterization of Cks1 At showed that overexpression of Cks1 in A. thaliana lead to a reduction in leaf growth and root growth rates due to elongated G1 and G2 phases of the cell cycle [99]. Similarly some parasitic animal models have also been used in certain studies to isolate and characterize homologs of the Cks1 protein. For instance Leishmania mexicana has been used to isolate $\mathrm{p} 12^{\mathrm{Cks} 1}$ which is the functional homolog of $\mathrm{p} 13^{\mathrm{Suc} 1}$ counterpart found in yeast $[95,100]$. Not surprisingly this protein was found to interact with yeast and bovine cdc2 as well as with CRK1 and SBCRK1 which are cdc2related kinases found in these parasites [95,100]. Recent studies with Branchiostoma belcheri (Amphioxus) have also suggested a potential developmental role of $\mathrm{Cks} 1$ [94]. Studies on Cks30 (Cks2 homologue in Drosophila) and Cks85A (Cks1 homologue in Drosophhila) have also demonstrated their role in female meiosis and mitosis during embryonic development, and maintenance of cell viability respectively [93,101-103].

In yet another report it was shown that Cks1 transcript levels gradually increase with increasing follicle size in bovine embryos possibly to ensure proper G2/M timing of cell cycle in the embryonic cells [82]. Skp2 and Cks1 also have been shown to play a crucial role in $\mathrm{S} / \mathrm{G} 2$ phase transition during adipocyte differentiation in 3T3-L1 preadipocytes [104]. Yu et al. have also recently demonstrated that a balance between Cks1 and Cks2 regulates $\mathrm{p} 27^{\mathrm{kip} 1}$ abundance and neuronal development in mouse embryonic cells [26]. Collectively these reports suggest novel roles of Cks family of protein in developmental biology which await further characterization. More recently Cks1 has also been shown to play a role in mitochondrial DNA replication regulating the mitochondrial single-stranded DNA-binding protein (mtSSB) function [105]. In another report demonstrating a p2 $7^{\text {kip } 1}$ independent Cks1 role it has been shown that Cks1 and Cks2 overexpression are involved in overcoming the DNA damage response following oncoprotein activation in breast cancer cells [27].

\section{Cks1-Implications in Breast and Other Cancers}

The importance of Cks1 in cancer progression can be understood given its pleiotropic roles in diverse biological processes that are known to be deregulated in cancer. Cks1 is overexpressed in a majority of human cancers and its expression is strongly correlated to tumor aggressiveness and dissemination of disease. Cks1 and its implications in cancers have been addressed herein by reviewing studies of Cks1 transcript levels, protein expression and gene amplification (the Cks1 gene is located on 1q21) in normal and/or cancer derived samples from patient cohorts of different cancer subtypes and their correlation to cancer clinicopathologic parameters. Because of its known role in the SCF-Skp2 complex many of these studies have also examined correlation of Cks1 expression to that of Skp2 and p2 $7^{\text {Kip1 }}$ or other cancer related markers (such as p53 and Ki-67) [106]. In general Cks1 expression is strongly correlated with Skp2 expression and inversely related to $\mathrm{p} 27^{\mathrm{Kip} 1}$ expression [106-109]. However many studies including ours have reported different trends in expression pattern of these three genes emphasizing potentially underappreciated $\mathrm{p} 27^{\mathrm{Kip} 1}$ independent mechanisms of $\mathrm{Cks} 1$ in cancer progression [110-112]. Another area of focus involves studies that attempt to determine the effect of Cks1 perturbation on cancer phenotypes (e.g. colony formation, migration and invasion, resistance to therapy etc.). For this discussion we broadly focus on two areas a) Cks1 expression, roles and implications in breast cancer, and b) Cks1 in other cancers.

\subsection{Cks1 and Breast Cancer}

We have found that normal mouse or rat tissues exhibit nearly undetectable levels of Cks1 protein, whereas both 
Cks1 mRNA and protein levels are very high in corresponding tumor tissues derived from mammary tumors excised from different murine models of mammary tumorigenseis (erbB2, c-myc and polyoma middle-T (PyMT) driven transgenic mice) and in carcinogen-initiated rat models [110]. In agreement with these studies a previous analysis of global gene expression patterns of mammary tumors initiated by the PyMT oncogene expressed in the context of five different genomic backgrounds revealed that Cks1 expression was greatly increased in PyMT-transgenic mammary tumors [113]. Interestingly, we found that $\mathrm{p} 27^{\text {Kip1 }}$ levels were not reduced, and were in fact slightly higher in mammary tumors initiated by erbB2, PyMT and MNU [110]. It is also known that the relative abundance of Cks1 SAGE tags in breast carcinoma tumor samples is higher compared to that in normal human mammary epithelium [114].

In one of the first studies that examined the role of Cks1 overexpression in human breast cancer Slotky et al. reported that Cks1 overexpression is associated with loss of tumor differentiation, younger age of patients, lack of expression of estrogen and progesterone receptors, decreased disease-free and overall survival [109]. Furthermore Cks1 and Skp2 expression was increased by estradiol in estrogen-dependent cell lines but were downregulated by tamoxifen [115]. In fact, in agreement with these findings we have previously demonstrated that stable overexpression of Cks1 in human breast carcinoma MCF-7 cells confers resistance to Faslodex (ICI-182780) whereas Cks1 knockdown led to a decrease in colony formation in estrogen-containing medium [110].

We have also shown that Cks1 depletion in MCF-7 breast cancer cells blocks cell cycle progression induced by both estrogen dependent and growth factor dependent pathways [70]. Cks1 depletion not only slows progression through G1-S, but also blocked their entry into M phase. Cks1 silencing also leads to a rapid loss of Skp2, concomitant increases in $\mathrm{p} 130 / \mathrm{Rb} 2$ and $\mathrm{p} 27^{\mathrm{Kip} 1}$, and marked reduction in the level of CDK1, which is essential for M phase entry. Interestingly Cks1 loss does not alter cell cycle profiles in human mammary epithelial cells or normal human lung fibroblast suggesting that targeting it might provide selectivity [70].

Given its importance in cancer progression it is not surprising that significant efforts have been directed to target Cks1 as a potential anti cancer target. Fluoxetine and Vorinostat are two drug candidates that have been shown to induce an accumulation of $\mathrm{p} 27^{\mathrm{Kip} 1}$ and $\mathrm{p} 21^{\mathrm{Cip} 1}$ and consequently cause cell cycle arrest through a Cks1 dependent mechanism in MDA-MB-231 breast cancer cells $[84,116]$. A DNA-microarray analysis to evaluate the anticancer effects of a dietary supplement Myco-
Phyto $^{\circledR}$ Complex (MC) has revealed that MC inhibits expression of Cks1 in MDA-MB-231 breast cancer cells suggesting a potential role for Cks1 targeting by chemopreventives [117]. An in silico screen targeting the phospho-p $27^{\text {Kip1 }}$ binding pocket led to development of a family four specific small molecule inhibitors collectively referred to as SKPins $(\mathrm{C} 1, \mathrm{C} 2, \mathrm{C} 16$, and $\mathrm{C} 20)$ that prevent the ubiquitination and degradation of $\mathrm{p} 27^{\mathrm{Kipl}}$ and $\mathrm{p} 21^{\mathrm{Cip} 1}$ exclusively by perturbing critical interactions that allow phospho-p $27^{\mathrm{Kip} 1}$ to bind in the pocket formed by Skp2-Cks1 [118-120]. This ultimately ensues in a cell type specific block in G1 or G2/M phase in T47D and MCF-7 respectively. Not surprisingly mutations in key residues mediating these contacts (for instance Cks1 Q52L) can reverse the inhibitory activity of some these compounds [120].

\subsection{Cks1 in Other Malignancies}

Expression analyses utilizing microarray platforms, qPCR studies and IHC analyses have revealed that Cks1 is overexpressed in different subtypes of lymphoma including mantle cell lymphoma (MCL) and mantle cell lymphoma blastoid variant (MCL-BV), and contributes to development of disease and resistance to cancer chemotherapy [121-124]. Studies delineating the precise mechanisms of Cks1 role in development and progression of lymphomas are still lacking however an important study in this regard has shown that Myc induced Cks1 can drive development of disease [81]. Loss of Cks1 markedly delays lymphoma development and dissemination of disease in the E $\mu$-Myc transgenic mouse lymphoma model [81]. Furthermore inhibition of PI3K/Akt pathways can decrease MCL growth by inducing $\mathrm{p} 27^{\mathrm{Kipl}}$ accumulation through Cks1 and Skp2 downregulation [17]. In yet another report it was found that retinoic acid downregulates the expression of the Cks1 and Skp2 proteins thus slowing down $\mathrm{p} 27^{\mathrm{Kip} 1}$ degradation in lymphoblastoid B cell lines [125].

Expression studies have employed fluorescent in situ hybridization and other methods to ascertain prevalence and prognostic significance of Cks1 gain following 1q21 amplification in multiple myeloma (MM) progression [126-129]. Cks1 gain is associated with transformation from benign monoclonal gammopathy of undetermined significance (MGUS) to more aggressive forms MM and plasma cell leukemias (PCL) and a shorter disease free survival [127]. Like lymphoma, little is known about detailed mechanisms of Cks1 in MM cells. However a study utilizing microarray based gene expression analysis of CD138 enriched plasma cells from MM patients undergoing melphalan based high dose therapy has suggested Skp2 and p2 $7^{\text {Kip1 }}$-dependent and independent mechanisms that fuel into multiple myeloma progression 
[130]. In fact Cks1 overexpression leads to multidrug resistance in multiple myeloma and stimulates STAT3 and MEK/ERK signaling pathways [21].

Cks1 is also highly overexpressed in the majority of different cancer subtypes afflicting the gastrointestinal system and in most cases is strongly correlated to increased Skp2 expression and reduced $\mathrm{p} 27^{\mathrm{Kip} 1}$ expression. Cks1 has been implicated in development of oral squamous cell carcinoma [131-133], salivary gland tumors [106], esophageal carcinomas $[80,134,135]$, gastric carcinoma $[20,136]$, colorectal carcinoma [108], gall bladder carcinoma [137] and hepatocellular carcinoma [19, 138-142]. Similarly Cks1 is believed to play a role in development and progression of several other types of cancers such as endometrial cancer [143], ovarian tumors [144-147], prostate cancer [148], testicular cancer [149], non small cell lung carcinomas (NSCLC) $[111,150]$, cutaneous squamous cell carcinoma [151], melanoma [15], urothelial carcinoma and renal cell carcinomas $[152,153]$, glioblastoma and CNS tumors [154,155], head and neck carcinoma [156], fibrosarcoma [157], and myxofibrosarcoma [158]. In many of these studies there is often a distinct correlation between Cks1 expression and clinicopathologic features such as tumor grade, stage, metastasis, loss of tumor differentiation patient prognosis and cancer free survival.

\section{Conclusion}

In conclusion, cellular and biochemical studies providing a clearer understanding of Cks1 and its function in cancer biology is likely to yield attractive avenues for therapeutic intervention.

\section{Acknowledgements}

Work in the authors' laboratory was supported by grants from the Komen Breast Cancer Foundation grant (BCTR00-456), IR\&D grant 1094, NCI Breast SPORE Developmental grant, Adolph Weil Endowment Fund and NIH (CA50376).

\section{REFERENCES}

[1] L. Yamasaki and M. Pagano, "Cell Cycle, Proteolysis and Cancer," Current Opinion in Cell Biology, Vol. 16, No. 6, 2004, pp. 623-628. http://dx.doi.org/10.1016/j.ceb.2004.08.005

[2] K. Vermeulen, D. R. Van Bockstaele and Z. N. Berneman, "The Cell Cycle: A Review of Regulation, Deregulation and Therapeutic Targets in Cancer," Cell Proliferation, Vol. 36, No. 3, 2003, pp. 131-149. http://dx.doi.org/10.1046/j.1365-2184.2003.00266.x

[3] M. Malumbres and M. Barbacid, "Cell Cycle, CDKs and Cancer: A Changing Paradigm," Nature Reviews Cancer, Vol. 9, No. 3, 2009, pp. 153-166.

\section{http://dx.doi.org/10.1038/nrc2602}

[4] C. J. Sherr and J. M. Roberts, "CDK Inhibitors: Positive and Negative Regulators of G1-Phase Progression," Genes \& Development, Vol. 13, No. 12, 1999, pp. 15011512. http://dx.doi.org/10.1101/gad.13.12.1501

[5] Z. Lu and T. Hunter, "Ubiquitylation and Proteasomal Degradation of the p21(Cip1), p27(Kip1) and p57(Kip2) CDK Inhibitors," Cell Cycle, Vol. 9, No. 12, 2010, pp. 2342-2352. http://dx.doi.org/10.4161/cc.9.12.11988

[6] S. I. Reed, "The Ubiquitin-Proteasome Pathway in Cell Cycle Control," Results and Problems in Cell Differentiation, Vol. 42, 2006, pp. 147-181.

http://dx.doi.org/10.1007/b136681

[7] A. Hershko and A. Ciechanover, "The Ubiquitin System," Annual Review of Biochemistry, Vol. 67, 1998, pp. 425479. http://dx.doi.org/10.1146/annurev.biochem.67.1.425

[8] K. I. Nakayama, S. Hatakeyama and K. Nakayama, "Regulation of the Cell Cycle at the G1-S Transition by Proteolysis of Cyclin E and p27Kip1," Biochemical and Biophysical Research Communications, Vol. 282, No. 4, 2001, pp. 853-860.

http://dx.doi.org/10.1006/bbrc.2001.4627

[9] S. Kotoshiba and K. Nakayama, "The Degradation of p27 and Cancer," Nihon Rinsho, Vol. 63, No. 11, 2005, pp. 2047-2056.

[10] R. J. Sheaff, et al., "Cyclin E-CDK2 Is a Regulator of p27Kip1," Genes \& Development, Vol. 11, No. 11, 1997, pp. 1464-1478. http://dx.doi.org/10.1101/gad.11.11.1464

[11] A. C. Carrano, et al., "SKP2 Is Required for UbiquitinMediated Degradation of the CDK Inhibitor p27," Nature Cell Biology, Vol. 1, No. 4, 1999, pp. 193-199. http://dx.doi.org/10.1038/12013

[12] D. Ganoth, et al., "The Cell-Cycle Regulatory Protein Cks1 Is Required for SCF(Skp2)-Mediated Ubiquitinylation of p27," Nature Cell Biology, Vol. 3, No. 3, 2001, pp. 321-324. http://dx.doi.org/10.1038/35060126

[13] C. Spruck, et al., "A CDK-Independent Function of Mammalian Cks1: Targeting of SCF(Skp2) to the CDK Inhibitor p27Kip1," Molecular Cell, Vol. 7, No. 3, 2001, pp. 639-650. http://dx.doi.org/10.1016/S1097-2765(01)00210-6

[14] C. A. Auld, C. D. Caccia and R. F. Morrison, "Hormonal Induction of Adipogenesis Induces Skp2 Expression through PI3K and MAPK Pathways," Journal of Cellular Biochemistry, Vol. 100, No. 1, 2007, pp. 204-216. http://dx.doi.org/10.1002/jcb.21063

[15] K. V. Bhatt, et al., "Mutant B-RAF Signaling and Cyclin D1 Regulate Cks1/S-Phase Kinase-Associated Protein 2Mediated Degradation of p27Kip1 in Human Melanoma Cells," Oncogene, Vol. 26, No. 7, 2007, pp. 1056-1066. http://dx.doi.org/10.1038/sj.onc.1209861

[16] D. F. Calvisi, et al., "Dual-Specificity Phosphatase 1 Ubiquitination in Extracellular Signal-Regulated KinaseMediated Control of Growth in Human Hepatocellular Carcinoma," Cancer Research, Vol. 68, No. 11, 2008, pp. 4192-4200. http://dx.doi.org/10.1158/0008-5472.CAN-07-6157

[17] C. J. Dal, et al., "Distinct Functional Significance of Akt 
and mTOR Constitutive Activation in Mantle Cell Lymphoma," Blood, Vol. 111, No. 10, 2008, pp. 5142-5151. http://dx.doi.org/10.1182/blood-2007-07-103481

[18] R. Hu and A. E. Aplin, "AlphaB-Crystallin Is Mutant BRAF Regulated and Contributes to Cyclin D1 Turnover in Melanocytic Cells," Pigment Cell \& Melanoma Research, Vol. 23, No. 2, 2010, pp. 201-209. http://dx.doi.org/10.1111/j.1755-148X.2010.00668.x

[19] E. K. Lee, et al., "Cell-Cycle Regulator Cks1 Promotes Hepatocellular Carcinoma by Supporting NF-kappaB-Dependent Expression of Interleukin-8," Cancer Research, Vol. 71, No. 21, 2011, pp. 6827-6835. http://dx.doi.org/10.1158/0008-5472.CAN-10-4356

[20] S. W. Lee, et al., "Akt and Cks1 Are Related with Lymph Node Metastasis in Gastric Adenocarcinoma," Hepatogastroenterology, Vol. 60, 2013, p. 127.

[21] L. Shi, et al., "Over-Expression of CKS1B Activates Both MEK/ERK and JAK/STAT3 Signaling Pathways and Promotes Myeloma Cell Drug-Resistance," Oncotarget, Vol. 1, No. 1, 2010, pp. 22-33.

[22] K. E. Simon, H. H. Cha and G. L. Firestone, "Transforming Growth Factor Beta Down-Regulation of CKShs1 Transcripts in Growth-Inhibited Epithelial Cells," Cell Growth \& Differentiation, Vol. 6, No. 10, 1995, pp. 12611269.

[23] S. Suzuki, et al., "Up-Regulation of Cks1 and Skp2 with TNFalpha/NF-kappaB Signaling in Chronic Progressive Nephropathy," Genes Cells, Vol. 16, No. 11, 2011, pp. 1110-1120. http://dx.doi.org/10.1111/j.1365-2443.2011.01553.x

[24] Y. Zhang, et al., "Direct Cell Cycle Regulation by the Fibroblast Growth Factor Receptor (FGFR) Kinase through Phosphorylation-Dependent Release of Cks1 from FGFR Substrate 2," Journal of Biological Chemistry, Vol. 279, No. 53, 2004, pp. 55348-55354.

http://dx.doi.org/10.1074/jbc.M409230200

[25] X. C. Wang, et al., "Overexpression of Cks1 Is Associated with Poor Survival by Inhibiting Apoptosis in Breast Cancer," Journal of Cancer Research and Clinical Oncology, Vol. 135, No. 10, 2009, pp. 1393-1401. http://dx.doi.org/10.1007/s00432-009-0582-8

[26] M. Frontini, et al., "The CDK Subunit CKS2 Counteracts CKS1 to Control Cyclin A/CDK2 Activity in Maintaining Replicative Fidelity and Neurodevelopment," Genes \& Development, Vol. 23, No. 2, 2012, pp. 356-370. http://dx.doi.org/10.1016/j.devcel.2012.06.018

[27] V. Liberal, et al., "Cyclin-Dependent Kinase Subunit (Cks) 1 or Cks2 Overexpression Overrides the DNA Damage Response Barrier Triggered by Activated Oncoproteins," Proceedings of the National Academy of Sciences of USA, Vol. 109, No. 8, 2012, pp. 2754-2759. http://dx.doi.org/10.1007/BF00331653

[28] J. Hayles, S. Aves and P. Nurse, "Suc1 Is an Essential Gene Involved in Both the Cell Cycle and Growth in Fission Yeast," EMBO Journal, Vol. 5, No. 12, 1986, pp. 3373-3379.

[29] J. Hayles, et al., "The Fission Yeast Cell Cycle Control Gene cdc2: Isolation of a Sequence suc1 That Suppresses cdc2 Mutant Function," Molecular and General Genetics,
Vol. 202, No. 2, 1986, pp. 291-293. http://dx.doi.org/10.1007/BF00331653

[30] S. I. Reed, et al., "Analysis of the Cdc28 Protein Kinase Complex by Dosage Suppression," Journal of Cell Science Supplement, Vol. 12, 1989, pp. 29-37. http://dx.doi.org/10.1242/jcs.1989.Supplement_12.4

[31] A. S. Arvai, et al., "Crystal Structure of the Human Cell Cycle Protein CksHs1: Single Domain Fold with Similarity to Kinase N-Lobe Domain," Journal of Molecular Biology, Vol. 249, No. 5, 1995, pp. 835-842. http://dx.doi.org/10.1006/jmbi.1995.0341

[32] Y. Bourne, et al., "Crystal Structure and Mutational Analysis of the Human CDK2 Kinase Complex with Cell Cycle-Regulatory Protein CksHs1," Cell, Vol. 84, No. 6, 1996, pp. 863-874.

http://dx.doi.org/10.1016/S0092-8674(00)81065-X

[33] J. A. Hadwiger, et al., "The Saccharomyces Cerevisiae CKS1 Gene, a Homolog of the Schizosaccharomyces Pombe suc1+ Gene, Encodes a Subunit of the Cdc28 Protein Kinase Complex," Molecular and Cellular Biology, Vol. 9, No. 5, 1989, pp. 2034-2041.

[34] J. Hindley, et al., "Sucl+ Encodes a Predicted 13-Kilodalton Protein That Is Essential for Cell Viability and Is Directly Involved in the Division Cycle of Schizosaccharomyces Pombe," Molecular and Cellular Biology, Vol. 7, No. 1, 1987, pp. 504-511.

[35] Y. Bourne, et al., "Crystal Structure and Mutational Analysis of the Saccharomyces cerevisiae Cell Cycle Regulatory Protein Cks1: Implications for Domain Swapping, Anion Binding and Protein Interactions," Structure, Vol. 8, No. 8, 2000, pp. 841-850. http://dx.doi.org/10.1016/S0969-2126(00)00175-1

[36] N. Khazanovich, et al., "Crystal Structure of the Yeast Cell-Cycle Control Protein, P13suc1, in a Strand-Exchanged Dimmer," Structure, Vol. 4, No. 3, 1996, pp. 299-309. http://dx.doi.org/10.1016/S0969-2126(96)00034-2

[37] H. E. Richardson, et al., "Human cDNAs Encoding Homologs of the Small p34Cdc28/Cdc2-Associated Protein of Saccharomyces cerevisiae and Schizosaccharomyces pombe," Genes \& Development, Vol. 4, No. 8, 1990, pp. 1332-1344. http://dx.doi.org/10.1101/gad.4.8.1332

[38] A. Satyanarayana and P. Kaldis, "Mammalian Cell-Cycle Regulation: Several Cdks, Numerous Cyclins and Diverse Compensatory Mechanisms," Oncogene, Vol. 28, No. 33, 2009, pp. 2925-2939.

http://dx.doi.org/10.1038/onc.2009.170

[39] R. Bader, et al., "Folding and Fibril Formation of the Cell Cycle Protein Cks1," The Journal of Biological Chemistry, Vol. 281, No. 27, 2006, pp. 18816-18824. http://dx.doi.org/10.1074/jbc.M603628200

[40] A. S. Arvai, et al., "Crystallization and Preliminary Crystallographic Study of Human CksHs1: A Cell Cycle Regulatory Protein," Proteins, Vol. 21, No. 1, 1995, pp. 7073. http://dx.doi.org/10.1002/prot.340210109

[41] D. Sitry, et al., "Three Different Binding Sites of Cks1 are Required for p27-Ubiquitin Ligation," The Journal of Biological Chemistry, Vol. 277, No. 44, 2002, pp. 4223342240. http://dx.doi.org/10.1074/jbc.M205254200

[42] B. Hao, et al., "Structural Basis of the Cks1-Dependent 
Recognition of p27(Kip1) by the SCF(Skp2) Ubiquitin ligase," Molecular Cell, Vol. 20, No. 1, 2005, pp. 9-19. http://dx.doi.org/10.1016/i.molcel.2005.09.003

[43] W. Wang, et al., "Molecular and Biochemical Characterization of the Skp2-Cks1 Binding Interface," The Journal of Biological Chemistry, Vol. 279, No. 49, 2004, pp. 51362-51369. http://dx.doi.org/10.1074/jbc.M405944200

[44] L. Brizuela, G. Draetta and D. Beach, "p13suc1 Acts in the Fission Yeast Cell Division Cycle as a Component of the p34cdc2 Protein Kinase," The EMBO Journal, Vol. 6, No. 11, 1987, pp. 3507-3514.

[45] D. Patra, et al., "The Xenopus Suc1/Cks Protein Promotes the Phosphorylation of $\mathrm{G}(2) / \mathrm{M}$ Regulators," The Journal of Biological Chemistry, Vol. 274, No. 52, 1999 , pp. 36839-36842.

http://dx.doi.org/10.1074/jbc.274.52.36839

[46] M. Koivomagi, et al., "Cascades of Multisite Phosphorylation Control Sic1 Destruction at the Onset of S Phase," Nature, Vol. 480, No. 7375, 2011, pp. 128-131. http://dx.doi.org/10.1038/nature 10560

[47] S. Xu, et al., "Substrate Recognition and Ubiquitination of SCFSkp2/Cks1 Ubiquitin-Protein Isopeptide Ligase," The Journal of Biological Chemistry, Vol. 282, No. 21, 2007, pp. 15462-15470. http://dx.doi.org/10.1074/jbc.M610758200

[48] A. Krishnan, S. A. Nair and M. R. Pillai, "Loss of Cks1 Homeostasis Deregulates Cell Division Cycle," Journal of Cellular and Molecular Medicine, Vol. 14, No. 1-2, 2010, pp. 154-164. http://dx.doi.org/10.1111/j.1582-4934.2009.00698.x

[49] T. Bashir and M. Pagano, "Don't Skip the G1 Phase: How APC/CCdh1 Keeps SCFSKP2 in Check. Cell Cycle, Vol. 3, No. 7, 2004, pp. 850-852. http://dx.doi.org/10.4161/cc.3.7.977

[50] J. W. Harper, "Protein Destruction: Adapting Roles for Cks Proteins," Current Biology, Vol. 11, No. 11, 2001, pp. R431-R435.

http://dx.doi.org/10.1016/S0960-9822(01)00253-6

[51] A. Krishnan, S. A. Nair and M. R. Pillai, "Loss of Cks1 Homeostasis Deregulates Cell Division Cycle," Journal of Cellular and Molecular Medicine, Vol. 14, No. 1-2, 2010, pp. 154-164.

http://dx.doi.org/10.1111/j.1582-4934.2009.00698.x

[52] J. Pines, "Cell Cycle: Reaching for a Role for the Cks Proteins," Current Biology, Vol. 6, No. 11, 1996, pp. 1399-1402.

http://dx.doi.org/10.1016/S0960-9822(96)00741-5

[53] J. Bartek and J. Lukas, "p27 Destruction: Cks1 Pulls the Trigger," Nature Cell Biology, Vol. 3, No. 4, 2001, pp. E95-E98. http://dx.doi.org/10.1038/35070160

[54] Y. Tang and S. I. Reed, "The Cdk-Associated Protein Cks1 Functions Both in G1 and G2 in Saccharomyces cerevisiae," Genes \& Development, Vol. 7, No. 5, 1993, pp. 822-832. http://dx.doi.org/10.1101/gad.7.5.822

[55] B. A. Schulman, et al., "Insights into SCF Ubiquitin Ligases from the Structure of the Skp1-Skp2 Complex," Nature, Vol. 408, No. 6810, 2000, pp. 381-386. http://dx.doi.org/10.1038/35042620
[56] G. Mulligan and T. Jacks, "The Retinoblastoma Gene Family: Cousins with Overlapping Interests," Trends in Genetics, Vol. 14, No. 6, 1998, pp. 223-229. http://dx.doi.org/10.1016/S0168-9525(98)01470-X

[57] X. Mayol and X. Grana, "The p130 Pocket Protein: Keeping Order at Cell Cycle Exit/Re-Entrance Transitions," Frontiers in Bioscience, Vol. 3, 1998, pp. d11-d24.

[58] D. Tedesco, J. Lukas and S. I. Reed, "The pRb-Related Protein $\mathrm{p} 130$ is Regulated by Phosphorylation-Dependent Proteolysis via the Protein-Ubiquitin Ligase SCF(Skp2)," Genes \& Development, Vol. 16, No. 22, 2002, pp. 29462957. http://dx.doi.org/10.1101/gad.1011202

[59] R. Wasch and D. Engelbert, "Anaphase-Promoting Complex-Dependent Proteolysis of Cell Cycle Regulators and Genomic Instability of Cancer Cells," Oncogene, Vol. 24, No. 1, 2005, pp. 1-10. http://dx.doi.org/10.1038/sj.onc.1208017

[60] L. Song and M. Rape, "Regulated Degradation of Spindle Assembly Factors by the Anaphase-Promoting Complex," Molecular Cell, Vol. 38, No. 3, 2010, pp. 369-382. http://dx.doi.org/10.1016/i.molcel.2010.02.038

[61] A. M. Fry and H. Yamano, "APC/C-Mediated Degradation in Early Mitosis: How to Avoid Spindle Assembly Checkpoint Inhibition," Cell Cycle, Vol. 5, No. 14, 2006, pp. 1487-1491. http://dx.doi.org/10.4161/cc.5.14.3003

[62] S. Kim and H. Yu, "Mutual Regulation between the Spindle Checkpoint and APC/C," Seminars in Cell \& Developmental Biology, Vol. 22, No. 6, 2011, pp. 551-558. http://dx.doi.org/10.1016/j.semcdb.2011.03.008

[63] R. H. Chen, "Dual Inhibition of Cdc20 by the Spindle Checkpoint," Journal of Biomedical Science, Vol. 14(4): 2007, pp. 475-479.

http://dx.doi.org/10.1007/s11373-007-9157-3

[64] J. Nilsson, et al., "The APC/C Maintains the Spindle Assembly Checkpoint by Targeting Cdc20 for Destruction," Nature Cell Biology, Vol. 10, No. 12, 2008, pp. 1411-1420. http://dx.doi.org/10.1038/ncb1799

[65] W. van Zon and R. M. Wolthuis, "Cyclin A and Nek2A: APC/C-Cdc20 Substrates Invisible to the Mitotic Spindle Checkpoint," Biochemical Society Transactions, Vol. 38, 2010, pp. 72-77. http://dx.doi.org/10.1042/BST0380072

[66] B. Di Fiore and J. Pines, "How Cyclin A Destruction Escapes the Spindle Assembly Checkpoint," Nature Cell Biology, Vol. 190, No. 4, 2010, pp. 501-509. http://dx.doi.org/10.1083/jcb.201001083

[67] R. Wolthuis, et al., "Cdc20 and Cks Direct the Spindle Checkpoint-Independent Destruction of Cyclin A," Molecular Cell, Vol. 30, No. 3, 2008, pp. 290-302. http://dx.doi.org/10.1016/j.molcel.2008.02.027

[68] D. Patra and W. G. Dunphy, "Xe-p9, a Xenopus Suc1/ Cks Protein, Is Essential for the Cdc2-Dependent Phosphorylation of the Anaphase-Promoting Complex at Mitosis," Genes \& Development, Vol. 12, No. 16, 1998, pp. 2549-2559. http://dx.doi.org/10.1101/gad.12.16.2549

[69] D. Patra and W. G. Dunphy, "Xe-p9, a Xenopus Suc1/ Cks Homolog, Has Multiple Essential Roles in Cell Cycle Control," Genes \& Development, Vol. 10, No. 12, 1996 pp. 1503-1515. http://dx.doi.org/10.1101/gad.10.12.1503 
[70] L. Westbrook, et al., "Cks1 Regulates Cdk1 Expression: A Novel Role during Mitotic Entry in Breast Cancer Cells," Cancer Research, Vol. 67, No. 23, 2007, pp. 11393-11401. http://dx.doi.org/10.1158/0008-5472.CAN-06-4173

[71] H. S. Martinsson-Ahlzen, et al., "Cyclin-Dependent Kinase-Associated Proteins Cks1 and Cks2 Are Essential during Early Embryogenesis and for Cell Cycle Progression in Somatic Cells," Molecular and Cellular Biology, Vol. 28, No. 18, 2008, pp. 5698-5709. http://dx.doi.org/10.1128/MCB.01833-07

[72] Y. S. Tsai, et al., "RNA Silencing of Cks1 Induced G2/M Arrest and Apoptosis in Human Lung Cancer Cells," IUBMB Life, Vol. 57, No. 8, 2005, pp. 583-589. http://dx.doi.org/10.1080/15216540500215531

[73] A. Hoellein, et al., "Cks1 Promotion of S Phase Entry and Proliferation Is Independent of p27Kip1 Suppression," Molecular and Cellular Biology, Vol. 32, No. 13, 2012, pp. 2416-2427. http://dx.doi.org/10.1128/MCB.06771-11

[74] S. Chaves, et al., "Cks1, Cdk1, and the 19S Proteasome Collaborate to Regulate Gene Induction-Dependent Nucleosome Eviction in Yeast," Molecular and Cellular Biology, Vol. 30, No. 22, 2010, pp. 5284-5294. http://dx.doi.org/10.1128/MCB.00952-10

[75] R. Holic, et al., "Cks1 Activates Transcription by Binding to the Ubiquitylated Proteasome," Molecular and Cellular Biology, Vol. 30, No. 15, 2010, pp. 3894-3901. http://dx.doi.org/10.1128/MCB.00655-09

[76] M. C. Morris, et al., "Cks1-Dependent Proteasome Recruitment and Activation of CDC20 Transcription in Budding Yeast," Nature, Vol. 423, No. 6943, 2003, pp. 10091013. http://dx.doi.org/10.1038/nature01720

[77] V. P. Yu, et al., "A Kinase-Independent Function of Cks1 and Cdk1 in Regulation of Transcription," Molecular Cell, Vol. 17, No. 1, 2005, pp. 145-151.

http://dx.doi.org/10.1016/j.molcel.2004.11.020

[78] D. J. Baker, et al., "Mitotic Regulation of the AnaphasePromoting Complex," Cellular and Molecular Life Sciences, Vol. 64, No. 5, 2007, pp. 589-600.

http://dx.doi.org/10.1007/s00018-007-6443-1

[79] L. J. Appleman, et al., "CD28 Costimulation Mediates Transcription of SKP2 and CKS1, the substrate Recognition Components of SCFSkp2 Ubiquitin Ligase That Leads p27kip1 to Degradation," Cell Cycle, Vol. 5, No. 18, 2006, pp. 2123-2129. http://dx.doi.org/10.4161/cc.5.18.3139

[80] M. Dibb, et al., "The FOXM1-PLK1 Axis Is Commonly Upregulated in Oesophageal Adenocarcinoma," British Journal of Cancer, Vol. 107, No. 10, 2012, pp. 17661775. http://dx.doi.org/10.1038/bjc.2012.424

[81] U. B. Keller, et al., "Myc Targets Cks1 to Provoke the Suppression of p27Kip1, Proliferation and Lymphomagenesis," The EMBO Journal, Vol. 26, No. 10, 2007, pp. 2562-2574. http://dx.doi.org/10.1038/sj.emboj.7601691

[82] M. Mourot, et al., "The Influence of Follicle Size, FSHEnriched Maturation Medium, and Early Cleavage on Bovine Oocyte Maternal mRNA Levels," Molecular Reproduction and Development, Vol. 73, No. 11, 2006, pp. 1367-1379. http://dx.doi.org/10.1002/mrd.20585
[83] V. Petrovic, et al., "FoxM1 Regulates Growth FactorInduced Expression of Kinase-Interacting Stathmin (KIS) to Promote Cell Cycle Progression," The Journal of Biological Chemistry, Vol. 283, No. 1, 2008, pp. 453-460. http://dx.doi.org/10.1074/jbc.M705792200

[84] N. Uehara, K. Yoshizawa and A. Tsubura, "Vorinostat Enhances Protein Stability of p27 and p21 through Negative Regulation of Skp2 and Cks1 in Human Breast Cancer Cells," Oncology Reports, Vol. 28, No. 1, 2012, pp. 105-110.

[85] I. C. Wang, et al., "Forkhead Box M1 Regulates the Transcriptional Network of Genes Essential for Mitotic Progression and Genes Encoding the SCF (Skp2-Cks1) Ubiquitin Ligase," Molecular and Cellular Biology, Vol. 25, No. 24, 2005, pp. 10875-10894. http://dx.doi.org/10.1128/MCB.25.24.10875-10894.2005

[86] W. Wang, et al., "Negative Regulation of SCFSkp2 Ubiquitin Ligase by TGF-Beta Signaling," Oncogene, Vol. Vol. 23, No. 5, 2004, pp. 1064-1075. http://dx.doi.org/10.1038/sj.onc.1207204

[87] K. Rother, et al., "Expression of Cyclin-Dependent Kinase Subunit 1 (Cks1) Is Regulated during the Cell Cycle by a CDE/CHR Tandem Element and is Downregulated by p53 but Not by p63 or p73," Cell Cycle, Vol. 6, No. 7, 2007, pp. 853-862. http://dx.doi.org/10.4161/cc.6.7.4017

[88] T. Bashir, et al., "Control of the SCF(Skp2-Cks1) Ubiquitin Ligase by the APC/C(Cdh1) Ubiquitin Ligase," Nature, Vol. 428, No. 6979, 2004, pp. 190-193. http://dx.doi.org/10.1038/nature02330

[89] D. J. Lenschow, T. L. Walunas and J. A. Bluestone, "CD28/B7 System of T Cell Costimulation," Annual Review of Immunology, Vol. 14, 1996, pp. 233-258. http://dx.doi.org/10.1146/annurev.immunol.14.1.233

[90] L. J. Appleman, et al., "CD28 Costimulation Mediates T Cell Expansion via IL-2-Independent and IL-2-Dependent Regulation of Cell Cycle Progression," The Journal of Immunology, Vol. 164, No. 1, 2000, pp. 144-151.

[91] M. Okamura, et al., "The Possible Mechanism of Enhanced Carcinogenesis Induced by Genotoxic Carcinogens in rasH2 Mice," Cancer Letters, Vol. 245, No. 1-2, 2007, pp. 321-330. http://dx.doi.org/10.1016/j.canlet.2006.01.025

[92] E. S. Polinko and S. Strome, "Depletion of a Cks Homo$\log$ in C. Elegans Embryos Uncovers a Post-Metaphase Role in Both Meiosis and Mitosis," Current Biology, Vol. 10, No. 22, 2000, p. 1471-1474. http://dx.doi.org/10.1016/S0960-9822(00)00808-3

[93] M. Ghorbani, et al., "Cks85A and Skp2 Interact to Maintain Diploidy and Promote Growth in Drosophila," Developmental Biology, Vol. 358, No. 1, 2011, pp. 213-223. http://dx.doi.org/10.1016/j.ydbio.2011.07.031

[94] H. Yang, et al., "Identification and Expression of the Amphioxus Cks1 Gene," Cell Biology International, Vol. 29, No. 7, 2005, pp. 593-597. http://dx.doi.org/10.1016/j.cellbi.2005.03.012

[95] J. C. Mottram and K. M. Grant, "Leishmania Mexicana p12cks1, a Homologue of Fission Yeast p13suc1, Associates with a Stage-Regulated Histone H1 Kinase," Biochemical Journal, Vol. 316 , 1996, pp. 833-839. 
[96] P. Colas, F. Serras and A. E. Van Loon, "Microinjection of Suc1 Transcripts Delays the Cell Cycle Clock in Patella Vulgata Embryos," The International Journal of Developmental Biology, Vol. 37, No. 4, 1993, pp. 589-594.

[97] V. Boudolf, et al., "Identification of Novel Cyclin-Dependent Kinases Interacting with the Cks1 Protein of Arabidopsis," Journal of Experimental Botany, Vol. 52, No. 359, 2001, pp. 1381-1382. http://dx.doi.org/10.1093/jexbot/52.359.1381

[98] L. De Veylder, et al., "The Arabidopsis Cks1At Protein Binds the Cyclin-Dependent Kinases Cdc2aAt and Cdc2bAt," FEBS Letters, Vol. 412, No. 3, 1997, pp. 446452. http://dx.doi.org/10.1016/S0014-5793(97)00822-3

[99] V. L. De, et al., "CKS1At Overexpression in Arabidopsis thaliana Inhibits Growth by Reducing Meristem Size and Inhibiting Cell-Cycle Progression," The Plant Journal, Vol. 25, No. 6, 2001, pp. 617-626.

[100] K. M. Grant, et al., "The Crk3 Gene of Leishmania Mexicana Encodes a Stage-Regulated cdc2-Related Histone H1 Kinase That Associates with p12," The Journal of Biological Chemistry, Vol. 273, No. 17, 1998, pp. 1015310159. http://dx.doi.org/10.1074/jbc.273.17.10153

[101] N. J. Pearson, et al., "A Pre-Anaphase Role for a Cks/ Suc1 in Acentrosomal Spindle Formation of Drosophila Female Meiosis," EMBO Reports, Vol. 6, No. 11, 2005, pp. 1058-1063. http://dx.doi.org/10.1038/sj.embor.7400529

[102] A. Swan, G. Barcelo and T. Schupbach, "Drosophila Cks30A Interacts with Cdk1 to Target Cyclin A for Destruction in the Female Germline," Development, Vol. 132, No. 16, 2005, pp. 3669-3678. http://dx.doi.org/10.1242/dev.01940

[103] A. Swan and T. Schupbach, "Drosophila Female Meiosis and Embryonic Syncytial Mitosis Use Specialized Cks and CDC20 Proteins for Cyclin Destruction," Cell Cycle, Vol. 4, No. 10, 2005, pp. 1332-1334. http://dx.doi.org/10.4161/cc.4.10.2088

[104] C. A. Auld, K. M. Fernandes and R. F. Morrison, "Skp2Mediated p27(Kip1) Degradation during S/G2 Phase Progression of Adipocyte Hyperplasia," Journal of Cellular Physiology, Vol. 211, No. 1, 2007, pp. 101-111. http://dx.doi.org/10.1002/jcp.20915

[105] M. Radulovic, et al., "CKS Proteins Protect Mitochondrial Genome Integrity by Interacting with Mitochondrial Single-Stranded DNA-Binding Protein," Molecular \& Cellular Proteomics, Vol. 9, No. 1, 2010, pp. 145-152. http://dx.doi.org/10.1074/mcp.M900078-MCP200

[106] R. M. Nagler, et al., "The Expression and Prognostic Significance of Cks1 in Salivary Cancer," Cancer Investigation, Vol. 27, No. 5, 2009, pp. 512-520. http://dx.doi.org/10.1080/07357900802239116

[107] M. Shapira, et al., "Alterations in the Expression of the Cell Cycle Regulatory Protein Cyclin Kinase Subunit 1 in Colorectal Carcinoma," Cancer, Vol. 100, No. 8, 2004, pp. 1615-1621. http://dx.doi.org/10.1002/cncr.20172

[108] D. D. Hershko and M. Shapira, "Prognostic Role of p27Kip1 Deregulation in Colorectal Cancer," Cancer, Vol. 107, No. 4, 2006, pp. 668-675. http://dx.doi.org/10.1002/cncr.22073
[109] M. Slotky, et al., "The Expression of the Ubiquitin Ligase Subunit Cks1 in Human Breast Cancer," Breast Cancer Research, Vol. 7, No. 5, 2005, pp. R737-R744. http://dx.doi.org/10.1186/bcr1278

[110] L. Westbrook, et al., "High Cks1 Expression in Transgenic and Carcinogen-Initiated Mammary Tumors Is Not Always Accompanied by Reduction in p27Kip1," International Journal of Oncology, Vol. 34, No. 5, 2009, pp. 1425-1431.

[111] N. Inui, et al., "High Expression of Cks1 in Human NonSmall Cell Lung Carcinomas," Biochemical and Biophysical Research Communications, Vol. 303, No. 3, 2003, p. 978-984.

http://dx.doi.org/10.1016/S0006-291X(03)00469-8

[112] S. Fredersdorf, et al., "High Level Expression of p27 (kip1) and Cyclin D1 in Some Human Breast Cancer Cells: Inverse Correlation between the Expression of p27 (kip1) and Degree of malignancy in human breast and colorectal cancers," Proceedings of the National Academy of Sciences of the United States of America, Vol. 94, No. 12, 1997, pp. 6380-6385.

http://dx.doi.org/10.1073/pnas.94.12.6380

[113] T. H. Qiu, et al., "Global Expression Profiling Identifies Signatures of Tumor Virulence in MMTV-PyMT-Transgenic Mice: Correlation to Human Disease," Cancer Research, Vol. 64, No. 17, 2004, pp. 5973-5981. http://dx.doi.org/10.1158/0008-5472.CAN-04-0242

[114] Y. Hu, et al., "From Mice to Humans: Identification of Commonly Deregulated Genes in Mammary Cancer via Comparative SAGE Studies," Cancer Research, Vol. 64, No. 21, 2004, pp. 7748-7755. http://dx.doi.org/10.1158/0008-5472.CAN-04-1827

[115] S. Signoretti, et al., "Oncogenic Role of the Ubiquitin Ligase Subunit Skp2 in Human Breast Cancer," Journal of Clinical Investigation, Vol. 110, No. 5, 2002, pp. 633641.

[116] A. Krishnan, et al., "Fluoxetine Mediates G0/G1 Arrest by Inducing Functional Inhibition of Cyclin Dependent Kinase Subunit (CKS)1," Biochemical Pharmacology, Vol. 75, No. 10, 2008, pp. 1924-1934.

http://dx.doi.org/10.1016/j.bcp.2008.02.013

[117] J. Jiang and D. Sliva, "Novel Medicinal Mushroom Blend Suppresses Growth and Invasiveness of Human Breast Cancer Cells," International Journal of Oncology, Vol. 37, No. 6, 2010, pp. 1529-1536.

[118] E. Rico-Bautista, et al., "Chemical Genetics Approach to Restoring p27Kip1 Reveals Novel Compounds with Antiproliferative Activity in Prostate Cancer Cells," $B M C B i$ ology, Vol. 8, 2010, p. 153.

http://dx.doi.org/10.1186/1741-7007-8-153

[119]E. Rico-Bautista and D. A. Wolf, "Skipping Cancer: Small Molecule Inhibitors of SKP2-Mediated p27 Degradation," Chemistry \& Biology, Vol. 19, No. 12, 2012, pp. 1497-1498.

http://dx.doi.org/10.1016/j.chembiol.2012.12.001

[120] L. Wu, et al., "Specific Small Molecule Inhibitors of Skp2-Mediated p27 Degradation," Chemistry \& Biology, Vol. 19, No. 12, 2012, pp. 1515-1524. http://dx.doi.org/10.1016/i.chembiol.2012.09.015 
[121] I. Urbanowicz-Kachnowicz, et al., "Ckshs Expression Is Linked to Cell Proliferation in Normal and Malignant Human Lymphoid Cells," International Journal of Cancer, Vol. 82, No. 1, 1999, pp. 98-104.

http://dx.doi.org/10.1002/(SICI)1097-0215(19990702)82: 1<98::AID-IJC17>3.0.CO;2-A

[122] S. de Vos, et al., "Cell cycle Alterations in the Blastoid Variant of Mantle Cell Lymphoma (MCL-BV) as Detected by Gene Expression Profiling of Mantle Cell Lymphoma (MCL) and MCL-BV," Diagnostic Molecular Pathology, Vol. 12, No. 1, 2003, pp. 35-43. http://dx.doi.org/10.1097/00019606-200303000-00005

[123] E. Bjorck, et al., "High Expression of Cyclin B1 Predicts a Favorable Outcome in Patients with Follicular Lymphoma," Blood, Vol. 105, No. 7, 2005, pp. 2908-2915. http://dx.doi.org/10.1182/blood-2004-07-2721

[124] N. Akyurek, et al., "Differential Expression of CKS-1B in Typical and Blastoid Variants of Mantle Cell Lymphoma," Human Pathology, Vol. 41, No. 10, 2010, pp. 1448-1455.

http://dx.doi.org/10.1016/j.humpath.2010.04.001

[125] P. Zancai, et al., "Retinoic Acid Stabilizes p27Kip1 in EBV-Immortalized Lymphoblastoid B Cell Lines through Enhanced Proteasome-Dependent Degradation of the p45Skp2 and Cks1 Proteins," Oncogene, Vol. 24, No. 15, 2005, pp. 2483-2494. http://dx.doi.org/10.1038/sj.onc. 1208458

[126] S J. haughnessy, “Amplification and Overexpression of CKS1B at Chromosome Band 1q21 Is Associated with Reduced Levels of p27Kip1 and an Aggressive Clinical Course in Multiple Myeloma," Hematology, Vol. 10, Suppl. 1, 2005, pp. 117-126.

http://dx.doi.org/10.1080/10245330512331390140

[127] H. Chang, et al., "Significant Increase of CKS1B Amplification from Monoclonal Gammopathy of Undetermined Significance to Multiple Myeloma and Plasma Cell Leukaemia as Demonstrated by Interphase Fluorescence in situ Hybridization," British Journal of Haematology, Vol. 134, No. 6, 2006, p. 613-615.

http://dx.doi.org/10.1111/j.1365-2141.2006.06237.x

[128]H. Chang, et al., "Multiple Myeloma Patients with CKS1B Gene Amplification Have a Shorter ProgressionFree Survival Post-Autologous Stem Cell Transplantation," British Journal of Haematology, Vol. 135, No. 4, 2006, pp. 486-491.

http://dx.doi.org/10.1111/j.1365-2141.2006.06325.x

[129] H. Chang, et al., "CKS1B Nuclear Expression Is Inversely Correlated with p27Kip1 Expression and Is Predictive of an Adverse Survival in Patients with Multiple Myeloma," Haematologica, Vol. 95, No. 9, 2010, pp. 15421547. http://dx.doi.org/10.3324/haematol.2010.022210

[130]F. Zhan, et al., "CKS1B, Overexpressed in Aggressive Disease, Regulates Multiple Myeloma Growth and Survival through SKP2- and p27Kip1-Dependent and -Independent Mechanisms," Blood, Vol. 109, No. 11, 2007, pp. 4995-5001.

[131] S. Kitajima, et al., "Role of Cks1 Overexpression in Oral Squamous Cell Carcinomas: Cooperation with Skp2 in Promoting p27 Degradation," American Journal of Pathology, Vol. 165, No. 6, 2004, pp. 2147-2155.
http://dx.doi.org/10.1016/S0002-9440(10)63264-6

[132] Y. Kudo, et al., "Down-Regulation of Cdk Inhibitor p27 in Oral Squamous Cell Carcinoma," Oral Oncology, Vol. 41, No. 2, 2005, pp. 105-116.

http://dx.doi.org/10.1016/j.oraloncology.2004.05.003

[133] G. Martin-Ezquerra, et al., "CDC28 Protein Kinase Regulatory Subunit 1B (CKS1B) Expression and Genetic Status Analysis in Oral Squamous Cell Carcinoma," Histology and Histopathology, Vol. 26, No. 1, 2011, pp. 71-77.

[134] J. J. Wang, et al., "Clinical Significance of Overexpressed Cyclin-Dependent Kinase Subunits 1 and 2 in Esophageal Carcinoma," Diseases of the Esophagus, 2013, in press. http://dx.doi.org/10.1111/dote.12013

[135] X. C. Wang, et al., "Overexpression of Cks1 Increases the Radiotherapy Resistance of Esophageal Squamous Cell Carcinoma," Journal of Radiation Research, Vol. 53, No. 1, 2012, pp. 72-78. http://dx.doi.org/10.1269/jrr.11090

[136] T. A. Masuda, et al., "Cyclin-Dependent Kinase 1 Gene Expression Is Associated with Poor Prognosis in Gastric Carcinoma," Clinical Cancer Research, Vol. 9, No. 15, 2003, pp. 5693-5698.

[137] S. H. Li, et al., "Skp2 Is an Independent Prognosticator of Gallbladder Carcinoma among p27(Kip1)-Interacting Cell Cycle Regulators: An Immunohistochemical Study of 62 Cases by Tissue Microarray," Modern Pathology, Vol. 20, No. 4, 2007, pp. 497-507. http://dx.doi.org/10.1038/modpathol.3800762

[138] C. W. Huang, et al., "CKS1B Overexpression Implicates Clinical Aggressiveness of Hepatocellular Carcinomas But Not p27(Kip1) Protein Turnover: An Independent Prognosticator with Potential p27 (Kip1)-Independent Oncogenic Attributes?" Annals of Surgical Oncology, Vol. 17, No. 3, 2010, pp. 907-922. http://dx.doi.org/10.1245/s10434-009-0779-8

[139] D. F. Calvisi, et al., "SKP2 and CKS1 Promote Degradation of Cell Cycle Regulators and Are Associated with Hepatocellular Carcinoma Prognosis," Gastroenterology, Vol. 137, No. 5, 2009, pp. 1816-1826. http://dx.doi.org/10.1053/j.gastro.2009.08.005

[140] D. F. Calvisi, et al., "The Degradation of Cell Cycle Regulators by SKP2/CKS1 Ubiquitin Ligase Is Genetically Controlled in Rodent Liver Cancer and Contributes to Determine the Susceptibility to The Disease," International Journal of Cancer, Vol. 126, No. 5, 2010, pp. 1275-1281.

[141] F. Feo, M. Frau and R. M. Pascale, "Interaction of Major Genes Predisposing to Hepatocellular Carcinoma with Genes Encoding Signal Transduction Pathways Influences Tumor Phenotype and Prognosis," World Journal of Gastroenterology, Vol. 14, No. 43, 2008, pp. 66016615. http://dx.doi.org/10.3748/wig.14.6601

[142]F. Feo, et al., "Genetic and Epigenetic Control of Molecular Alterations in Hepatocellular Carcinoma," Experimental Biology and Medicine, Vol. 234, No. 7, 2009, pp. 726-736. http://dx.doi.org/10.3181/0901-MR-40

[143] K. T. Huang, et al., "Estrogen and Progesterone Regulate p27kip1 Levels via the Ubiquitin-Proteasome System: Pathogenic and Therapeutic Implications for Endometrial Cancer," PLoS ONE, Vol. 7, No. 9, 2012, Article ID: 
e46072. http://dx.doi.org/10.1371/journal.pone.0046072

[144] V. Ouellet, et al., "Discrimination between Serous Low Malignant Potential and Invasive Epithelial Ovarian Tumors Using Molecular Profiling," Oncogene, Vol. 24, No. 29, 2005, pp. 4672-4687. http://dx.doi.org/10.1038/sj.onc.1208214

[145] V. Ouellet, et al., "Tissue Array Analysis of Expression Microarray Candidates Identifies Markers Associated with Tumor Grade and Outcome in Serous Epithelial Ovarian Cancer," International Journal of Cancer, Vol. 119, No. 3, 2006, pp. 599-607. http://dx.doi.org/10.1002/ijc.21902

[146] S. Yamamoto, et al., "Cumulative Alterations of p27-Related Cell-Cycle Regulators in the Development of Endometriosis-Associated Ovarian Clear Cell Adenocarcinoma," Histopathology, Vol. 56, No. 6, 2010, pp. 740749. http://dx.doi.org/10.1111/j.1365-2559.2010.03551.x

[147] S. Yamamoto, et al., "Aberrant Expression of p27(Kip1)Interacting Cell-Cycle Regulatory Proteins in Ovarian Clear Cell Carcinomas and Their Precursors with Special Consideration of Two Distinct Multistage Clear Cell Carcinogenetic Pathways," Virchows Arch, Vol. 455, No. 5, 2009, pp. 413-422. http://dx.doi.org/10.1007/s00428-009-0844-5

[148] Y. Lan, et al., "Aberrant Expression of Cks1 and Cks2 Contributes to Prostate Tumorigenesis by Promoting Proliferation and Inhibiting Programmed Cell Death," International Journal of Cancer, Vol. 123, No. 3, 2008, pp. 543-551. http://dx.doi.org/10.1002/ijc.23548

[149] K. Miyai, et al., "Altered Expression of p27(Kip1)-InterActing Cell-Cycle Regulators in the Adult Testicular Germ Cell Tumors: Potential Role in Tumor Development and Histological Progression," APMIS, Vol. 120, No. 11, 2012, pp. 890-900. http://dx.doi.org/10.1111/j.1600-0463.2012.02919.x

[150] V. G. Zolota, et al., "Histologic-Type Specific Role of Cell Cycle Regulators in Non-Small Cell Lung Carcinoma," Journal of Surgical Research, 164, No. 2, 2010, pp. 256-265. http://dx.doi.org/10.1016/j.jss.2009.03.035

[151] R. Salgado, et al., "CKS1B Amplification Is a Frequent Event in Cutaneous Squamous Cell Carcinoma with Ag- gressive Clinical Behaviour," Genes, Chromosomes and Cancer, Vol. 49, No. 11, 2010, pp. 1054-1061.

http://dx.doi.org/10.1002/gcc.20814

[152] K. Kawakami, et al., "Increased SKP2 and CKS1 Gene Expression Contributes to the Progression of Human urothelial Carcinoma," Journal of Urology, Vol. 178, No. 1, 2007, pp. 301-307. http://dx.doi.org/10.1016/j.juro.2007.03.002

[153]Z. Liu, et al., "Prognostic Implication of p27Kip1, Skp2 and Cks1 Expression in Renal Cell Carcinoma: A Tissue Microarray Study," Journal of Experimental \& Clinical Cancer Research, Vol. 27, 2008, p. 51. http://dx.doi.org/10.1186/1756-9966-27-51

[154] D. M. Kokkinakis, et al., "Modulation of Gene Expression in Human Central Nervous System Tumors under Methionine Deprivation-Induced Stress," Cancer Research, Vol. 64, No. 20, 2004, pp. 7513-7525. http://dx.doi.org/10.1158/0008-5472.CAN-04-0592

[155] H. Halfter, et al., "Oncostatin M Induces Growth Arrest by Inhibition of Skp2, Cks1, and Cyclin A Expression and Induced p21 Expression," Cancer Research, Vol. 66, No. 13, 2006, pp. 6530-6539. http://dx.doi.org/10.1158/0008-5472.CAN-04-3734

[156] R. Lin, et al., "Inhibition of F-Box Protein p45(SKP2) Expression and Stabilization of Cyclin-Dependent Kinase Inhibitor p27(KIP1) in Vitamin D Analog-Treated Cancer Cells," Endocrinology, Vol. 144, No. 3, 2003, pp. 749753. http://dx.doi.org/10.1210/en.2002-0026

[157] D. M. Gascoyne, et al., "Loss of Mitotic Spindle Checkpoint Activity Predisposes to Chromosomal Instability at Early Stages of Fibrosarcoma Development," Cell Cycle, Vol. 2, No. 3, 2003, pp. 238-245. http://dx.doi.org/10.4161/cc.2.3.355

[158] H. Y. Huang, et al., "Skp2 Overexpression Is Highly Representative of Intrinsic Biological Aggressiveness and Independently Associated with Poor Prognosis in Primary Localized Myxofibrosarcomas," Clinical Cancer Research, Vol. 12, No. 2, 2006, pp. 487-498. http://dx.doi.org/10.1158/1078-0432.CCR-05-1497 